Encounters on Education

Volume 4, Fall 2003 pp.145-166

\title{
Learning to Teach Citizenship: A Lifelong Learning Approach
}

\author{
Daniel Schugurensky and J ohn P. Myers \\ Ontario Institute for Studies in Education of the University of Toronto (OISE/UT)
}

\begin{abstract}
W here do civics teachers learn about the content and methods of civics education? W hat is the impact of these learning experiences on their teaching approaches? D riven by these questions, we undertook a study with civics teachers in O ntario, C anada. Whereas citizenship education is often understood as occurring exclusively in formal schooling, and the preparation for teaching civics is usually conceived as occurring in pre-service teacher training, in this study we uncovered civic learning that occurs in nine formal, informal and nonformal settings: early family socialization to primary school, secondary school, pre-service training, other university programs, workshops and conferences, civic participation, the media, and the teaching of civics itself. In relation to the first question, the teachers reported that through a variety of lifelong and lifewide experiences they acquired different amounts and types of learning on civic knowledge, civic values, civic and political skills, political beliefs, and civics teaching.

In order to address the second question, we explored the relationship between the civic learning experienced by teachers, on the one hand, and the content and methods of their teaching, on the other. The settings were found to differentially influence the competencies and pedagogical orientations that civics teachers bring to their classrooms. Informal settings, especially the family and civic participation, were particularly important for teaching about the workings of the political process and for modeling practices of political engagement. Even within the same setting, experiences that produced different impacts were identified. For instance, while the impact of the secondary school curriculum was negligible overall, some interviewees recalled one or two high school teachers as role models who would later influence their own teaching approaches. This study found that teachers' learning experiences, particularly those acquired through their own teaching of civics, provide them with competencies and attitudes that influence both their teaching approaches as well as their levels of political enlightenment and engagement.
\end{abstract}

Key words: Lifelong citizenship learning, teacher leaming, civics teaching, structure-agency dynamics, pedagogical knowledge

\section{RESUMEN}

¿D ónde aprenden los docentes de educación ciudadana los contenidos y los métodos de dicha asignatura? ¿Cuál es el impacto de estas experiencias de aprendizaje en sus abordajes pedagógicos? Guiados por estas preguntas, realizamos un estudio son docentes de educación ciudadana de la provincia de $\mathrm{O}$ ntario, C anadá. Si bien la educación ciudadana tiende a conceptualizarse como una actividad que ocurre exclusivamente en la escuela, y la preparación para la enseñanza de esta 
materia tiende a ser concebida como una actividad que ocurre en los programas de formación docente, en este estudio exploramos aprendizajes ciudadanos que ocurren en una variedad de espacios educativos formales, no formales e informales. Estos espacios incluyen desde la socialización primaria a la escuela primaria, la secundaria, la formación docente, cursos universitarios y de desarrollo profesional, talleres y seminarios, participación ciudadana, medios de comunicación, y la propia experiencia docente. Los docentes entrevistados que a través estas experiencias de aprendizaje a lo largo y a lo ancho de sus vidas han adquirido diferentes niveles y tipos de conocimientos cívicos, valores cívicos, habilidades cívicas y políticas, preferencias políticas, y estrategias pedagógicas para la educación ciudadana.

En relación con la segunda pregunta, este estudio exploró la relación entre los aprendizajes ciudadanos adquiridos por los docentes, por un lado, y los contenidos y métodos de su práctica docente, por otro. Los resultados sugieren que cada espacio de aprendizaje influye de manera diferente sobre las competencias y orientaciones pedagógicas que los docentes Ilevan al aula. Los espacios informales, por ejemplo, la socialización familiar y la participación ciudadana, parecer ser particularmente importantes para la enseñanza de los procesos políticos y para modelar prácticas de involucramiento político. Aun dentro del mismo espacio se identificaron experiencias de aprendizaje que produjeron resultados impactos diferentes. Por ejemplo, si bien el impacto del curriculum de la escuela secundaria fue insignificante, al gunos docentes protagonizaron un al to efecto inspirador actuando como model os. El estudio también nota que, a través de experiencias de aprendizajes informales, los docentes adquirieron competencias y actitudes que pueden influir en sus estrategias pedagógicas.

Descriptores: Aprendizajes ciudadanos a lo largo de la vida; aprendizaje docente, enseñanza de civismo, relación estructura-agencia, conocimiento pedagógico

\section{RÉSUMÉ}

O ù les enseignants de civisme apprennent-ils le contenu et les méthodes de l'éducation civique? Q uel est l'impact de ces expériences d'apprentissage sur leurs approches pédagogiques? Poussés par ces questions, nous avons entrepris une étude avec les enseignants de civisme en O ntario, au C anada. Alors que l'éducation au civisme est souvent comprise comme ayant lieu exclusivement en instruction formelle, et que la préparation à l'enseignement du civisme est ordinairement conçue comme ayant lieu en formation de pré-service à l'enseignement, dans cette étude nous avons découvert un apprentissage civique qui se produit dans une variété de cadres, formels, informels et non-formels. De tels cadres varient de la première socialisation familiale à l'école primaire, à l'école secondaire, à la formation de pré-service, à d'autres programmes universitaires, à des ateliers et congrès, à la participation civique, les média et l'enseignement du civisme même. Les enseignants interviewés rapportent qu'à travers ces expériences à longueur et à largeur de vie, ils acquièrent différentes sommes et types d'apprentissage en connaissances civiques, en valeurs civiques, en habiletés civiques et politiques, en convictions politiques et en pédagogie du civisme.

Afin d'aborder la seconde question, l'étude explore aussi la relation entre l'apprentissage civique expérimenté par les enseignants, d'une part, et le contenu et les méthodes de leur enseignement, d'autre part. On a trouvé que les cadres influencent différentiellement les compétences et les orientations pédagogiques que les enseignants de civisme apportent à leur classe. Les cadres informels, spécialement la participation familiale et civique, étaient particulièrement importants pour apprendre les mécanismes du processus politique et pour offrir des modèles pratiques de participation politique. $D$ ans le même cadre, des expériences qui produisaient des impacts différents ont même été identifiées. Par exemple, al ors que l'impact du curriculum scolaire était négligeable en général, l'impact de certains enseignants qui sont devenus des modèles de rôles était considérable parmi certaines personnes interviewées. C ette étude a aussi trouvé que les expériences d'apprentissage informelles des enseignants leur fournissent des compétences et des attitudes qui peuvent fortement influencer leurs approches pédagogiques.

Mots-cléfs: Citoyenneté tout le long de la vie, apprentissage des enseignantes/enseignants, l'enseignement civique, dynamique structurelle-agentive, savoir pédagogique 


\section{Introduction}

$\mathrm{N}$ edUCATIONAL Circles it is often said that once teachers close the classroom door, they enjoy a certain degree of autonomy that allows them to create learning experiences for their students. To some extent, they feel free to provide what they consider the most appropriate content, teaching methods, and classroom environment for their learners. This freedom is relative, of course, because what teachers do in the classroom must be aligned with the prescribed curriculum, a situation that is particularly pronounced in the context of testing regimes. ${ }^{1}$ It is also relative because what teachers do and say in the classroom have political implications, particularly when addressing issues (historical or current) that are deemed controversial in a given community or that deviate from the expectations of the government, parents or school authorities. This freedom/constraint continuum varies from country to country and from province to province, depending on historical, social and institutional circumstances.

M uch has been said in the educational literature about this dynamic relation between structure and agency. We know that teachers have some agency. H owever, we don't know much about the ways in which this agency is shaped throughout their lives. For instance, what are the biographical factors that influence teachers to adhere to or deviate from the official curriculum and from pedagogical norms? As Apple (1990) pointed out, teachers are not just instructors of what other people decided they should teach. $M$ any teachers are also curricul um planners, community leaders and organizers, and political activists in movements for a more just society. Indeed, teachers bring to the classroom a great variety of past and present experiences. M oreover, teaching itself is an important source of experience. All these experiences are sources of learning, which, sometimes tacitly, sometimes explicitly, influence teaching approaches and practices. ${ }^{2}$

This exploratory study deals precisely with the connections between lifelong learning and teaching, a topic that has not received much scholarly attention. Because of our particular interest on citizenship and political learning, we chose to collect the learning and teaching stories of civics teachers. Through biographical interviews, we delved into the impact of learning settings on civics teaching. 0 ur guiding hypothesis is that teachers' pedagogical choices are frequently shaped (consciously or unconsciously, and in different ways and degrees) by lifelong learning experiences that span from early family socialization to the present. We are aware that these practices are also influenced by institutional, professional and social pressures, but this is a topic for another paper.

This study took place in the context of a new open-level ${ }^{3}$ provincial civics course for grade 10 in 0 ntario, Canada that was initiated during the 2000-01 school year. The new 0 ntario civics curriculum includes three conceptual strands, as it strives to develop a citizenship that is active, informed and purposeful ( 0 ntario $M$ inistry of Education and Training, 1999). The civics curriculum conceives of education for active citizenship as the skills that are necessary for civic participation and the opportunities for applying these skills in civic activities. The guidelines state that "full participatory citizenship requires an understanding of practices used in civic affairs to influence public decision making." The emphasis on active citizenship placed in the guidelines was particularly 
noticeable to educators, and to some extent surprising, because of the conservative leanings of the government in turn. H owever, at the level of implementation, the concept of 'active citizenship' is often understood as mandatory community service (frequently volunteer work and apprenticeships in workplaces), leaving aside the preparation of students for participation in the affairs of the state or in social and political organizations.

We conducted in-depth interviews with fifteen high school civics teachers in Greater Toronto. The interviews explored their civic learning in nine 'learning settings': 1) family socialization; 2) elementary schooling; 3 ) secondary schooling; 4) preservice training; 5) higher education programs; 6) the media; 7) nonformal education (including in-service teacher training, professional development, adult education courses and workshops); 8) political engagement and community involvement; and 9) the teaching of civics. ${ }^{4}$ For each setting, we asked interviewees to reflect on the impact of the learning acquired there on five key domains: civic knowledge, civic values, civic and political skills, political beliefs, and teaching of civics (seetable 1).

Table 1: Civic Learning Settingsand D omains

\begin{tabular}{ll}
\hline Learning settings & Learning domains \\
\hline Family & Civic knowledge \\
Primary School & Civic values \\
Secondary school & Civic and political skills \\
Pre-service & \\
O ther university & Political beliefs \\
N on-formal & \\
Civic participation & Teaching of civics \\
M edia & \\
Teaching civics & \\
\hline
\end{tabular}

In a previous paper (Schugurensky \& M yers, 2002) we described the civic learning in these settings and domains. Here we focus on the relationship of the different learning settings to civics teaching. We should note that the teaching of civics was conceptualized both as a learning setting (another way to put it would be 'workplace learning') and as a learning domain. This is not insignificant because, as we will see later, this setting was recognized by teachers as the most powerful learning space for the teaching of civics.

During the interviews, civics teachers were asked to recall and examine their personal learning experiences in the different settings, and to reflect on how this learning affects their classroom teaching. At the end of the interview, participants were asked to fill out a short questionnaire assessing the relative influence of each setting on their teaching. Teachers who participated in the study had taught the new course at least once, and had at least one year of teaching experience. As teachers of citizenship education, they were particularly well-positioned to reflect on and understand their own lifelong citizenship learning, as well as to establish links between such learning and their teaching experience. Participants were invited to join the study through 
teacher professional organizations and school contacts. Their ages ranged between 25 and 55 years, and just over half were between the ages of 25 and 34 . All of the interviewees were born in $\mathrm{C}$ anada, and two identified themselves as visible minorities. Females constituted about two-thirds of the sample. The teaching experience of the interviewees ranged between one and thirty years, with an average of 6.8 years. Just over one-half have earned graduate degrees. In terms of family background, $79 \%$ of the interviewees have at least one parent with post-secondary education.

\section{Teaching civics and lifelong learning: exploring the connections}

As areas of educational research, citizenship education and lifelong learning have infrequently crossed paths. Citizenship education is considered crucial to the strengthening of democratic societies through the development of enlightened, critical and engaged citizens, but is largely concentrated in formal schooling for children, especially in the content area of the social studies. In Canada, citizenship education has been described as the central purpose of the social studies (Sears, 1997). D espite this importance, the significance of teachers' learning has often been overlooked in citizenship education research. Lifelong learning, on the other hand, is premised on the recognition that learning occurs throughout the lifespan, that it takes place in formal, nonformal and informal settings, and that it should be nurtured, funded and recognized. Although it is sometimes viewed in economic and individualistic terms, such as in human capital and neoliberal approaches, lifelong learning can also be conceived of as a liberating and transformative strategy that seeks to empower groups through inclusive citizenship and social action (Aspin \& Chapman, 2000 and 2001; Baptiste, 1999; Elliot, 2000; Gorard et al., 1999; Johnston, 1999; M artin, 2000). Lifelong learning is rooted in the field of adult education, and has largely been a concern of international policymaking organizations, especially in N orth America and Western Europe.

In this study, learning is conceived of as occurring in constant interaction between the self and the environment (Bandura, 1977; Vygotsky, 1978). Social learning theory is the basis for exploring the ontological dimension of lifelong learning (as different from its policy dimension) through the lives and teaching practices of social studies teachers. An ontological lifelong learning approach assumes that people build their understandings and beliefs from a variety of learning experiences that take place in multiple social settings. In this ontological approach, lifelong learning is not conceived of as an orderly, uninterrupted and linear accumulation of learning experiences. Instead, we conceptualize it as a complex set of experiences that can complement or contradict each other. We al so considered the insights of constructivism, which can be summarized in three basic premises: 1) learners construct understanding by themselves, in interaction with others and with their environment; 2) understanding is based on establishing relationships, which involves logical as well as socio-emotional connections; and 3) establishing relationships depends upon prior knowledge (Lowery, 1997; Piaget, 1965). 
The third premise is particularly relevant for this study. For instance, we al ready know from the research literature that early family socialization plays an important role in the development of values, orientations and dispositions. Adults who were raised in households in which family members shared decision-making and those who attended schools in which students' opinions were taken seriously are more likely to develop personal confidence, which in turn increases the likelihood of political participation. We also know that political efficacy can be nurtured by the family's social and cultural capital (Berger \& Luckman, 1966; Bourdieu, 1986; M ishler \& Clarke, 1995).

To these three constructivist premises, our conceptual framework adds a fourth one, which is rooted in the contributions of D ewey and Freire: learning takes place in the context of institutional, social and political realities, and can contribute to reproduce or transform those realities (D ewey, 1938; Freire, 1970). ${ }^{5}$ Based on these premises and findings, we are particularly interested in the connection between prior learning experiences and teaching practices, and in the ways in which such connection is mediated by institutional and social contexts. Studies of teachers' life stories (through biographies and autobiographies) have a long tradition, and have been very helpful in explaining teachers' real practices by relating them to teachers' past experiences. These interpretations and critical studies have provided a solid base to map the ways in which teachers' perspectives (and their teaching practices) are rooted in the variety of personal, financial, religious, political and cultural experiences (Zeichner \& Gore, 1990). There is, for instance, an important body of research aiming at understanding how teachers' acculturation processes influence their classroom attitudes and behavior towards students, particularly in relation to issues of race, class, and gender. This literature includes narratives describing and explaining how the life experiences of white teachers often act as a barrier to the schooling of students of color (C anfield, 1970; D ecker, 1969; Dilworth, 1990; Grant, 1999; Parkay, 1983).

A related research tradition uses the concept of 'teacher knowledge', which refers to the interaction between teachers' informal development of worldviews, beliefs and understandings, on the one hand, and their formal, professional views on teaching and learning, on the other. A substantial proportion of teachers' knowledge is tacit, although sometimes it becomes explicit through teacher education programs or inservice workshops aiming at uncovering and critically examining held assumptions. In the field of teacher knowledge, the term 'personal practical knowledge' refers to the role of teacher's tacit knowledge in their day-to-day practice of teaching. This knowledge is a complex set of practically oriented understandings of self, instruction, subject matter, curriculum development and the larger social context. For this tradition, teachers' life experiences, thinking and knowledge profoundly influence their pedagogical approaches, and constitute the dominant knowledge base that teachers use in their classroom practice (Connelly \& Clandinin, 1988; Connelly, Clandinin, \& $\mathrm{He}$, 1997). Likewise, contemporary research on social studies teachers illustrates different ways in which teachers' life experiences and beliefs influence their teaching practices (Chant, 2002; Cornett, 1990; Fickel, 2000; Powell, 1992 and 1998).

There is also a considerable body of research on the interactions between teacher candidates' beliefs about teaching and pre-service education. Teacher education 
researchers have consistently found that prospective teachers' beliefs and assumptions influence the process of learning to teach during the preservice teaching program. At the same time, however, the preservice learning experience (especially through methods courses and practicum experiences) can alter those beliefs (Angell, 1998; FeimanNemser \& Buchmann, 1989; Knowles \& H olt-Reynolds, 1991; Sears \& Perry, 2000).

Learning to teach, then, is a complex cognitive process grounded in school and life experiences, which in turn influence the development of personal theories of education. An important aspect of these studies is the highlighting of teachers' agency in shaping and adapting the prescribed social studies curriculum. Personal theories of education derive from life experiences and include beliefs about the aim of education, the origin of knowledge, the nature of learning, and an image of the teacher. Teachers who have the opportunity to reflect on their biographical experiences are better equipped to take a critical approach to their own practice. H owever, the social and cultural context of schools can be a limiting factor on teachers attempts to incorporate their personal theories in their teaching.

This tension is particularly evident in the case of civic education. When the state demands a biased curriculum, teachers who aren't ideologically committed to the regime or whose pedagogical beliefs refuse to indoctrinate students face a hard choice: to compromise their professional standards, or to lose their jobs (H eater, 1990). This situation is clear in totalitarian regimes, but the dilemma exists - in less obvious expressions - in any society with a trace of authoritarianism. In most countries, civics teachers feel pressure to conform to state political orientations, to prevailing ideologies in society, and even to symbols. In some countries, for instance, singing the national anthem, raising the flag and other patriotic school rituals are mandatory, and teachers refusing to participate in these ceremonies can be punished. Another inhibiting factor is the institutional culture of the school. The first international survey of civic education, conducted in the seventies, concluded that "... perhaps a hierarchical organization such as the school is not the right setting for inculcating democratic values" (Torney-Purta et al., 1975, p. 21). This study informed us that the educational systems were unsuccesful in producing, among all their students, citizens who were well-informed, held democratic attitudes and values, and were interested in civic affairs.

Unfortunately, the present situation is not dramatically different. A follow-up study in the nineties of 24 countries reveals that there is still a wide gap between the goals for democracy expressed in the curriculum and the reality of the society and school, and expresses a concern about teacher preparation for civics teaching (Torney-Purta, Schwille, \& Amadeo, 1999). Although experts in the 24 countries agreed that civic education should be interdisciplinary, participative, interactive, life-centered, conducted in a non-authoritarian environment, cognizant of the challenges of equity and diversity, and co-constructed with parents, the community, and non-governmental organizations, very few schools have achieved these goals. This is confirmed by other studies released during the past decade (Braungart \& Braungart, 1998; H ébert \& Wilkinson, 2002; Ichilov, 1998; Sears, 1994; Sears, Clarke \& Hughes, 1999). These studies assert that citizenship education today is less restrictive and has more ecological sensitivities than it did in the past, but still focuses on the legal and structural aspects of politics, neglecting controversial and global issues, and fostering passivity and compliance. 
If the contradiction between democratic ideals and non-democratic classrooms is not only observable in the gap between theory and practice, but also in the tensions between policy rhetoric and policy implementation, and between teachers' pedagogical statements and their pedagogical actions. For instance, how do we explain that some civics teachers talk about democracy but create an authoritarian classroom environment, proclaim active student participation but rely primarily on lectures, advocate critical thinking but emphasize memorization of information, or support pluralism and autonomy but cannot stand students who have a different viewpoint? As D arder (1999) reminds us, it is possible to be politically correct and pedagogically wrong. This potential dissonance between 'democratic speak' and non-democratic pedagogy ${ }^{6}$ can be found indeed in a variety of democratic attitudes and competencies.

Listening, for example, is considered one of the key pedagogical practices of democratic citizenship (Bickford, 1996; Forester, 1980; G uttman \& Thompson, 2000; Vella, 1994; Welton, 2002). Yet listening (which is not necessarily the sameas agreeing) should not be taken for granted. The disposition to listen with respect and with an open mind to those who think differently than us is not an innate trait. It must be cultivated through social situations characterized by democratic dialogue, pluralism, empathy and respect. In the research on participatory democracies, the capacity (and the attitude) to listen is regularly mentioned by participants as one of the most important changes experienced by them as a result of participating in the deliberative process (Abers, 2000; Schugurensky, 2002). H owever, since participatory democracy is an exceptional rather than a normal setting, listening must be learned in a variety of spaces.

Indeed, democratic dialogue can be learned in institutions like the family, the school or the church, although these institutions tend to operate (for reasons that may be justified) on a hierarchical basis. It can al so be learned through political life, especially when it is not characterized by adversarial debates, monologues and self-righteous speeches. This situation is especially important for civics teachers. As a hypothesis, we suggest that if teachers have had the opportunity to nurture and deepen their own listening attitudes and skills, they will be more capable of instilling them in their students. This hypothesis, which we call the 'learning-teaching dissonance', can be extended to other attitudes and behaviors. T he expectation is that experiential learning is as important as or more important than abstract learning. T his dissonance helps to explain why teacherstend to teach in the same way they were taught in school, even if this contradicts the pedagogical theories learned in preservice training.

Although constraints exist, we reiterate, teachers have choices that can be negotiated differently in each particular context. The exercise of those choices begins with clarifying their own pedagogical approach to civics by making explicit the tacit. A first step in this process consists of posing questions to themselves (H utchinson, 1989; M agsino, 2003). They could ask, for instance: what kind of civic virtues, values, dispositions and capacities do I aim at nurturing among my students? Should I put an emphasis on individual entitlements, on personal autonomy, on social solidarity, or on pluralism and the acknowledgment of difference? Should I instill patriotism or cosmopolitanism? Should I cultivate passive or active citizenship? Should I promote rote memorization, obedience and system maintenance, or critical analysis, collective 
action and social change? Should I make explicit my own perspective to avoid manipulation, or should I hide my views to avoid indoctrination?"

In answering these questions, teachers are guided by certain assumptions that derive from political-ideological approaches (e.g. conservative, liberal, marxist, communitarian, republican, feminist, environmental, etc.), from a set of moral, ethical and religious values, from a repertoire of pedagogical principles and practices, and from their own educational, work and life experiences. In other words, teachers' strategies are likely to be influenced by the degree of control or permissiveness that characterizes each institution and political environment in each societal context. At the same time, teachers' willingness to adhere to or deviate from the norm are likely to be influenced by factors like personality, support networks, ideological orientations and pedagogical beliefs, and prior learning experiences. Returning to our initial proposition, when civics teachers close the doors of their classrooms, they bring with them a wealth of experiences and knowledge, and a set of assumptions that influence the way they approach the teaching of civics. This is the theme that we tried to explore in our interviews.

\section{Citizenship leaming and teaching: teachers talk}

For the purposes of presentation, we have organized teachers' rich narratives about their lifelong and lifewide civic learning, and about the ways in which different learning experiences influenced their civics teaching, in two key dimensions of democratic citizenship: political enlightenment and political engagement. Enlightenment refers to the holding of democratic values, norms and knowledge, whereas engagement refers to political participation, and implies acquiring knowledge about political actors and policies, recognizing one's political interests, and participating in political and civic activities (N ie, Junn \& Stehlik-Berry, 1996). While these dimensions may seem to be inherent elements of any citizenship education curriculum, they are not typically addressed in preservice programs. Thus, it is unclear how teachers learn about them in any considerable depth or sophistication. As H oward (1999) points out in reference to multicultural education, "we can't teach what we don't know." This is particularly relevant in civics education, which is concerned with social action on issues and processes in the local, national and global communities, and the political attitudes, skills and knowledge needed to be engaged. As a hypothesis for future research, we suggest that civics teaching is optimized when teachers have broad and relevant civic learning experiences.

In this regard, M cEwan (1994) argues that teachers should have an opportunity to experience firsthand the freedom and choices that delineate the role of citizens in a democracy. For her, teachers cannot empower students if they do not understand what it means to be personally empowered themselves. In her own words, "if future teachers never have an opportunity to personally experience the balance of individual rights and group responsibilities, it seems reasonable to suppose they might not be able to impart this information to their students in a way that is meaningful and lasting" (M cEwan, 1994, p. 104). At the same time, a series of studies published during the nineties reveal that most teacher education programs are not preparing teachers 
adequately to teach students so that they can participate fully in democracy (Gollnick, 1991; Grant, 1994 and 1999; Grant \& Secada, 1990; Zimpher \& Ashburn, 1992).

In addition to the two dimensions of enlightenment and engagement, the interviewees made other connections between their civic learning and their civic teaching. These comments were grouped in a third area, which can be called 'pedagogical knowledge', and refers to the understanding of teaching strategies and approaches. The strategies and approaches mentioned (and reflected upon) by the interviewees were not al ways specific to civics, al though some were clearly more relevant to this subject than to others. The pedagogical strategies that were cited as influencing their present teaching were often drawn from the interviewees' past experiences as students and from their current teaching practice.

\section{Enlightenment: we can't teach what we don't know}

The formation of values and the acquisition of knowledge related to civics were frequently associated with formal primary and secondary education. D emocratic values, such as respect and tolerance, were identified as the main influence of primary schooling on teaching. While overall primary education was only recalled by a minority of the study participants, they recalled the emphasis on these values and have incorporated them in their relationships and interactions with students and through the management of their classrooms. In a few cases, values and interests that were formed through experiences in secondary education influenced the curricular choices that teachers made. These interests informed teachers' decisions about what to teach. For example, one teacher was influenced by his participation in an environmental club as a high school student.

The acquisition of civic knowledge had a strong effect on the participants' teaching, which was acquired predominantly in the settings of post-secondary education and through the media. Courses in university were cited as providing the knowledge base in political science and history that are a necessary foundation for teaching civics.

Especially taking history courses, you learn so much it makes you want to do more. In civics, you can. That probably comes out of the passion to make that little difference and do something, which would come out in my teaching today. You learn content and this content inspires you to do things.

U sing current events was found to be an important teaching strategy in the civics classroom. Several interviewees reported using the media to make the course rel evant by incorporating discussion of current issues and by critically examining their coverage.

I have tapes and I have the kids watch segments of the prime minister debates and the candidates tal king on issues. N ewspapers, we read them on the internet. I follow the news like some of the breaking news, the problems we're having with the $C$ anadian Alliance.

Another class, using media literacy strategies, analyzed the political perspectives of newspapers: 
I think vested interests is a big one, editorial perspective... I'll ask them to think about what are the biases, what are the editorial points of views informing this position. And who stands to gain that there are certain positions you can expect from The Globe or The N ational Post that you may not necessarily see in The Star and why is that?

Families were not cited as having a strong influence on the interviewees' teaching approach. However, one teacher mentioned the importance of kitchen table conversations as a complement of class activities, something that was part of her own socialization.

My socialization instilled in me a democratic value system, and this influenced the way that I approach the teaching of civics in that I encourage my students to have an open dialogue with their family members on political and social issues that we discuss in class. This helps students to understand different opinions and to develop their own views.

\section{Engagement: we can't teach what we don't do}

Teachers' personal understandings of citizenship are important in the new civics course due to its focus on the practice of citizenship through student participation in civic activities and community service. It has been suggested that for teachers to be competent in civic education, they need civic knowledge, skills and values beyond academic knowledge (Kennedy, 1998). In the absence of adequate preservice and inservice training, it is expected that they would draw heavily on their own life experiences and understandings.

Engagement draws primarily from informal learning and civic experiences. Participants learned about political engagement through opportunities that allowed them to see how politics worked behind the scenes, such as through contact with politicians. This most often occurred in families that were active in politics. 0 ne of the study participants described how she learned about politicians through her father's work and how this positioned her to provide a more sophisticated understanding of politics in her class. This experience allowed her to provide an insider's understanding of the workings of the political process for her students:

$M$ y father had a business, a store where sometimes these people would come in during election campaigns. So I knew who these people were and knew what their role was and I admired some and disliked others. I guess that made me aware of the importance of political leadership. That's something that I try to convey to the students that these are, on the one hand, they're not gods but on the other hand they're not complete devils either. They're human beings that are the best that we've got, maybe, or maybe not the best but, to take a kind of critical view of them but not just throw them all into the same garbage heap, which is what the tendency seems to be with politicians today. 
In teaching about political engagement, teachers most often drew from their own participation in political activities. Indeed, several interviewees reported using their civic and political experience to model participatory behaviors to their students.

I guess the way it influences me is that everyone, including myself, must make some sort of difference in going back to being that role model. You must do things, or you must talk about it or you must be an informed citizen. That comes across in my teaching because that's what I say. I don't make it seem as though it's something you can or cannot do. It's something that you must do if you have the luxury of living in the society that we do, where there is an actual true democracy unlike other places that aren't true democracies.

Some interviewees mentioned that their own experience of civic participation provides them with a feeling of legitimacy for teaching a civics course, and also allows them to share their own frustrations, accomplishment and lessons learned with their students. These teachers do not always portray themselves as ideal citizens who fulfill every civic duty, but they try to become decent role models for their students. The following two quotes provide some illustrations of this 'pedagogy of example':

I think it's important for people to be informed citizens, purposeful and active citizens. These are terms but I think that there's a truth in them that, first of all you have to know what's going on in order to make an informed decision about what to vote and who you're going to vote for, and to encourage them to be involved and to participate. I try to do that as much as I can. I don't always do it, sometimes I become disillusioned and withdraw for a while. I think that's going to be normal too. But I always felt that it's important to lead by example and encouraging kids to be active politically you should demonstrate that you've donethat yourself.

We stress and the guidelines stress becoming an active citizen so I show students examples of where I'm involved. Because sometimes we're teaching something and the kids say, 'you don't do this, miss', and I say 'yeah, I do'. I do this, do that, I just don't publicize it but I'm an active citizen and I take part in different things. If the highway is going through my backyard I'm going to say something.

These comments support the contention that political experiences provide affective as well as cognitive support to teaching about civics, something particularly relevant to the new civics course because of its emphasis on active citizenship. Both quotes tell something about the connections between political engagement and civics teaching. Some civics teachers (as suggested in the first quote) present themselves as human beings, and not as full-time 'supercitizens' who are al ways civically engaged. The second quote suggests that civics teachers do not tend to boast about their civic and political involvement, but if the occasion arises, they are prepared to talk about what they have done as citizens, and provide an example of engagement for their students. 


\section{Pedagogical knowledge: we don't need to teach the way we learned}

Civics teachers reported that their pedagogical knowledge is derived from a variety of learning sources. To begin with, several interviewees commented on the influence played by an inspirational teacher in secondary school, preservice or university. Either because of a particular teaching style, a pedagogical philosophy, certain personality traits, or all of the above, these inspirational teachers seem to have played a crucial role in the professional lives of our interviewees. The influence could be expressed in different ways, from nurturing a passion for citizenship education to developing a particular perspective on content, or using a certain set of methods and techniques. Some interviewees pointed out that one inspirational teacher sometimes can shape a teaching career, or a particular interest for civics. This confirms the insights of other biographical and autobiographical accounts of civics teachers. For instance, Ken O sborne, one of the leading Canadian authors in the field of citizenship education, once reported that his enthusiasm for history began not because of the subject itself but because of one particular teacher (0 sborne, 1991).

It is pertinent to clarify that not all the influences from past schooling experiences were necessarily positive. Sometimes, as we will se below, a frustrating school experience can also have an influence on teaching strategies, as a negative example. In general, the interviewees' civic learning in elementary school, for those who recalled having civic experiences, had a weak influence on their current civic teaching. In most of these cases, the impact that it had on their current teaching was negative. They described the teaching method in elementary school as authoritarian, intimidating and restrictive of free expression. Active democracy was seldom nurtured. For instance, one teacher recalled that "... unfortunately, at the elementary school there was not an outlet in which we could actively participate in promoting democracy." O ur interviewees stated that they consciously strive to avoid teaching in this manner as a result of their experience, and one reflected on better understanding and recognizing the teacher's power in the classroom:

Well to do it differently from the way some of the teachers I had then did: not to allow any kind of dissent, or to discourage it, or to promote a kind of view that was the conventional wisdom. Just as a negative, I suppose I try not to do those things because I al ways felt frustrated by that myself when I was a student.

Several teachers stated that their experience in secondary school did not influence how they teach today, while others stated that it was a moderate influence. Secondary education was often a negative influence because, the interviewees noted, their courses were taught with an authoritarian approach and the course content was unrelated to civic participation. O ne teacher recall led: "T he things that I'm doing now, the debating and the discussion groups, they never did that. It was really a lot more structured, more structured even than what I'm doing." H owever, some interviewees noted that they drew pedagogical ideas from their most inspirational teachers in secondary school. Some teaching moments are still fresh in their memory and act as resources for their current practice: 
That teacher [in high school] purposely always played the opposite of what maybe some of the students who were clued in knew just to try to get a rise out of us and get us debating about things. This strategy is something that I do in all of my classes. I try to take the opposite side just to try to make it interesting and engage them in debate so that they can see and defend their point of view and maybe even see mine to a certain extent. I can remember it quite vividly, but if it's a passion for you, you tend to remember things like that.

Some interviewees also recalled meeting a particular inspirational professor at the university, and referred to the long lasting influence of that professor on their present teaching approaches and strategies:

My professor in first year later became a leader of the NDP, and I had a lot of respect for him. Some other professors I had were politically active. I think more than that was observing good teaching at the university level and I was fortunate to have some very good professors who influenced not just the way I might teach civics but the way I would teach anything, the approach I take to teaching in general. You have to translate it to the high school level, which is a little different but not a lot of different.

Preservice was consistently cited as an important source for learning teaching strategies relevant to the new civics course. As one interview pointed out, this learning builds upon their first teaching experiences in the preservice program:

Through my pre-service teaching experiences I learned about pedagogical strategies that allow students to investigate issues. This influenced my teaching of civics tremendously as it acted as a valuable resource, especially at the beginning of my teaching career. (0 ur emphasis)

This quote highlights the significance of the practicum experience in preservice teaching as well as the role of experiential learning in teacher preparation. It also tells us that "learning by teaching" starts in preservice. Teacher training had a moderate impact on the particularities of civics teaching. The impact on content knowledge was particularly low, probably due to the fact that in most cases their preservice training did not focus on civics (as we mentioned before, this is a relatively new subject matter in the school curriculum). H owever, teacher training did influence the way the interviewees teach civics today through their acquisition of teaching methods, especially finding ways to make lessons relevant to the students. Progressive teaching, while recognized as very important by the interviewees, was of a generic nature, applicable to different subject matters, and not specifically directed towards the teaching of civics.

$\mathrm{H}$ e always had an impact on me in terms of not just sitting around and reading books but teaching skills and getting students to do things and then to get that learning to transform them, to turn them into more active citizens. I think he was way back then working on this concept of active citizenship and then the $\mathrm{N}$ ew C urriculum came around and obviously it was a fit for him. 
Teachers reported that the greatest influence on their civics teaching is the learning gained from the experience of teaching civics. Through the questionnaires and interviews, they indicated that the classroom is a significant learning space because it allowed them to experiment with new methodologies, lesson plans and teaching materials. This "learning by doing" is informed by their past school experiences: some teachers noted that they try to avoid repeating what they found frustrating and aim to emulate what they found effective or inspiring.

N onformal education settings were another important source for pedagogical knowledge mentioned by the interviewees. This includes a variety of inservice training activities. Through these courses and workshops, teachers learn about a range of strategies, including role playing, values education, critical thinking and other participatory models to promote active citizenship skills. O ne teacher pointed out that after taking a workshop she began to incorporate cooperative learning strategies in her civics classroom. For her, "cooperative learning is fundamental to teaching civics, because it nurtures social and interpersonal skills to participate in groups, and students learn to listen to the opinions of others."

\section{Summary and Conclusions}

This study explored when, where and how civics teachers in Toronto learned about democratic citizenship, and the influence of this learning on their teaching. We hypothesized that teachers' approaches to teaching civics are shaped by a great variety of lifelong and lifewide learning experiences, and that these experiences have significant yet qual itatively differing degrees of influence on their teaching. Indeed, civics teachers reported that their teaching is informed -in different ways and at different levels of intensity- by a constellation of learning experiences that were acquired in the nine settings: family, primary school, secondary school, pre-service training, university degrees, nonformal education, political participation, media, and teaching itself.

All learning settings, with the exception of primary education, had at least a moderate influence on teaching civics. While family socialization was highly influential for the learning of values, political beliefs, and civic knowledge, and to lesser extent political engagement, it constituted the second weakest influence (primary education was the weakest) on civics teaching. Secondary school exerted a weak to moderate influence. Although some teachers were motivated by one or two inspiring, committed and engaged teachers who brought life to politics, the majority of interviewees recalled that experience as learning passive citizenship through simple memorization of facts. Interestingly enough, such negative experience played a role in making some of the interviewees more determined to create a positive and participatory learning environment for their students.

Preservice training was moderately influential, although teachers held divergent views on the usefulness and relevance of the actual courses in these settings, and on the qualities of the instructors. D espite considerable influence on teaching methodology, pre-service training appeared to have a weak influence (in relation to other settings) in 
the development of civic knowledge, attitudes, values and skills. The issue of preservice training of civics teachers seems to be a problem in many parts of the world.

The media also influenced the interviewees' teaching methodologies, largely through their use of the television news and newspaper articles to make civics topics relevant to the students' lives and community. $\mathrm{N}$ on-formal education (including additional qualifications and in-service training) had a moderate impact on their teaching repertoire, especially in relation to pedagogical methods. A moderate influence was also attributed to university courses, particularly in reference to civic knowledge and political understanding.

O verall, however, the single most influential setting for learning the competencies for civics teaching was clearly civics teaching itself. This type of informal, workplace learning was recurrently pointed out by teachers as their main source of learning, and the one with the highest impact in improving their teaching and even their civic competencies. Why did the teachers' own experiences of teaching had the greatest impact on their teaching practices, far more than any other learning setting? We have two complementary explanations for this. First, the 0 ntario civics course was a new subject matter in the curriculum, and teachers were learning its content as they went along and testing its methods by trial and error. This was particularly clear in the case of young teachers or those with little teaching experience. Secondly, learning on the job is a powerful site of learning. Through activities like planning curriculum, preparing activities and lectures, evaluating assignments, assisting students with critical analysis of political discourses and with civic engagement projects, and other teaching-related tasks, civics teachers gain a great deal of civic knowledge and pedagogical competencies.

In the case of these civics teachers, then, the old pedagogical principle of 'learning by doing' means mainly 'learning by teaching'. W hile their prior learning experiences in a variety of formal, non-formal and informal settings clearly influence their pedagogical approach and teaching practices, it is also clear that the most important source of learning (both about civics and about the teaching of civics) is their own practice of teaching civics itself. D eveloping curriculum and course materials, preparing for class, listening to students, guest speakers and audiovisual materials, helping students to write letters, organize an human rights campaign, or critically analyze electoral platforms are just some examples of activities that provide teachers not only a significant amount of pedagogical expertise, but also a great deal of civic knowledge, skills and attitudes.

O ne could argue that this is the case for any other teaching activity. To some extent, we agree. H owever, because citizenship education is fundamentally about learning to engage in collective practices for defining how society functions, it equips teachers with a better understanding of the political process and with more refined competencies to influence it. As Kennedy (1998) notes, teaching civics affords numerous learning opportunities to teachers because it is not an intellectual game with predictable outcomes and with low relevance to real life challenges. Teaching a second language or mathematics does not al ways provide the same learning opportunities for teachers as teaching civics does, for two reasons. First, citizenship and democracy are dynamic and fluid fields, and its content changes constantly according to current political 
realities. Second, civics is about engagement in issues and ideas that fundamentally affect the way we live. $\mathrm{H}$ ence, it is not surprising that the civics teachers we interviewed, particularly those who were passionate about their teaching, noted that they acquired considerable knowledge and skills by working on civic projects with their students, and consistently ranked teaching civics as their main source of civic learning. In a virtuous circle, this learning improves their teaching. Indeed, to teach civics effectively, Kennedy argues, teachers must be engaged in these issues, analyze different perspectives, examinetheir own beliefs, and eventually take positions.

'Learning by teaching' is something that occurs almost naturally. Just as children learn about their world by playing its scripts, teachers learn about teaching and learning by playing the teaching script, observing what happens, and discussing possibilities with other teachers (J ones, 1993). U nfortunately, however, these learning activities are seldom initiated, encouraged or supported by the school. It is ironic that schools rarely foster learning among teachers: they are asked to create and sustain conditions that make school learning and school living stimulating for children, but not for themselves. As a result, the longer teachers work in a school, the less excited, alive, or stimulated they are likely to be. Although teachers tend to perceive their work as important, the routine and the scarcity of learning opportunities can place their work on the "boring side" (Jones, 1993; Sarason, 1972).

Furthermore, we can ask with Proefriedt (1994, p. 128): "To what extent can the schools in which the teachers work become institutions in which the teachers learn as well as teach?" If the school is considered a locus of teachers' learning, teachers could render their work lives educative and the disconnection between school and life would decrease. Following D ewey's call for reconnecting education to life, one of the tasks for teachers is to reconstruct their experience in the school and use it as an educational text. For this, teachers can nurture their learning by 'reading' their own teaching experience, both alone (through reflective journals) and with others (in dialogue with colleagues who are also reflecting on their work). In regards to the latter, it is important that teachers find colleagues from whom they can learn, whom they can trust to be supportive and honestly critical, and who themselves are open to new perspectives on their teaching (Connelly \& Clandinin, 1988; D ucharme \& Ducharme, 1999; Liston, \& Zeichner, 1993; M cD onald, 1992; M cN ergney et al. 1999; Proefriedt, 1994).

Past learning experiences can affect the way we teach in different ways. In a recent study with 16 adult educators about the influence of their past school experiences on their current educational beliefs, Taylor (2003) reported five main findings: (a) past positive teacher models mirror present descriptions of ideal teachers and present descriptions of self as a teacher; (b) past positive teaching experiences are about making the act of imparting knowledge more engaging and interesting; (c) past positive learning experiences relate to present conceptions of learning; (d) past conceptions of self as a student reflect present expectations of adult students; and (e) past cultural experiences are reflected in present descriptions of adult students. The findings of this study confirm several of Taylor's results, although our interviewees noted that a school experience does not need to be al ways positive to influence good teaching. Indeed, it was pointed out more than once that the frustrating school experiences of the past can also play a role in 
promoting good teaching practices today, as negative examples. As our interviewees stated, the bad memories of schooling are a helpful reminder to save students the same frustrating experience, and an incentive to do things differently this time.

In closing, this study brings new light to the understanding of the connections between the learning and the teaching of civics. It shows the different impact of teachers' learning experiences, both past and present, on teaching and on active citizenship. It paves the way for further studies on civics teachers' learning biographies, which could assist us not only in identifying the place, date and context of particular learning episodes, but also - and more importantly - on better comprehending their influence (positive and negative) on civic teaching and on civic engagement. Since the most significant source of learning about teaching civics found in this study was teaching civics itself, the first policy implication derived from this finding is to design institutional ways to nurture and improve, in each school, the al ready existing processes of 'learning by teaching'. The second policy implication is to find ways to improve the civic learning experience in elementary and secondary schools, and in pre-service training. If these courses are also about the promotion of active citizenship, we need to find creative ways to put civic engagement at the center of the learning experience. This will assist in developing more and better 'teacher democrats' willing and able to teach the basics of democratic citizenship through democratic processes.

\section{Notes}

1. A recent study on state mandated tests suggests that high stakes tests continually forces teachers to act in ways they do not think are professional and often results in creating instructional environments that teachers do not think are conducive to student success (M athison \& Freeman, 2003). The pressure to' teach to the test' obviously reduces the level of autonomy of teachers to provide al ternative learning experiences.

2. For a pioneering work on tacit knowledge, see Polanyi (1966).

3. "O pen-level" refers to a course in which the students are not selected and sorted according to ability.

4. We also included the category 'other' as a potential tenth civic learning setting, but none of the interviewees made reference to any learning setting in addition to the nine that we proposed. We expect that in future interviews more learning settings may be identified.

5. See al so the works of Foley (1999) and $\mathrm{H}$ all (1999) on social movement learning.

6. A high school teacher interviewed by Kahne and Westheimer (2003), for instance, made the following statement in relation to civics education: "M y goal is to empower students to rectify problems, to come up with solutions, and to join with other people so that they can become truly active citizens" (p. 35). This statement, which echoes D ewey and the progressive education tradition, is no different from many other statements that we have heard from civics teachers. The question is: to what extent do we practice what we preach? Available research has not yet found a definite answer to this one. A good ethnographic contribution addressing this issue can be found in Pruyn's (1999) discourse analysis taking place in a critical education program with Latin American immigrants in Los Angeles.

7. On the issue of indoctrination, one high school teacher, active in the environmental movement, made this point: "W hen one thinks of teachers as activists and agents of social change, we need to be aware of the power difference between the teacher and student. Even though a teacher may work hard to present all sides of an issue before explaining where he or she stands on that issue, is it actually possible for a student to come to up to his own 
conclusions given that power differential?". This question was echoed by another teacher. She asked: "H ow can we engage in democratic, transformative learning without imposing ideas and playing the role of indoctrinator? $\mathrm{H}$ ow can we actively promote antiauthoritarianism in a way that is not-authoritarian?"

\section{References}

Abers, R. (2000). Inventing local democracy: G rassroots politicsin Brazil. Boulder, Co.: Lynne Rienner Publishers.

Angell, A. (1998). Learning to teach social studies: A case study of belief restructuring. Theory and Research in Social Education, 26(4), 509-529.

Apple, M. (1991). Introduction. In D . Liston \& K. M. Zeichner (1991), Teacher education and the social conditions of schooling (pp. vii-xii). N ew York: Routledge.

Aspin, D . and C hapman, J. (2001). Lifelong learning: concepts, theories and values. Proceedings of the 31st. Annual conference of SCUTREA: T he Standing Conference on University Teaching and Research in the Education of Adults. U niversity of East London, IK, 38-41.

Aspin, D . and C hapman, J. (2000). Lifelong learning: C oncepts and conceptions. International J ournal of Lifel ong Education, $19(1), 2-19$.

Bandura, A. (1977). Social learning theory. Englewood Cliffs, N J: Prentice-H all.

Baptiste, I. (1999). Beyond lifelong learning: a call to civically responsible change. International Journal of Lifelong Learning, 18(2), 94-102.

Berger, P. and Luckmann, T. (1966). The social construction of reality. A treatisein the sociology of knowledge N ew York: D oubleday.

Bickford, S. (1996). The di ssonance of democracy: Listening, conflict and citizenship. Ithaca, N Y: Cornell U niversity Press.

Bourdieu, P. (1986). The forms of capital (R. N ice, Trans.). In J. Richardson (Ed.), H andbook of theory and research for the sociology of education (pp. 241-258). N ew York: Greenwood Press.

Braungart, R. and Braungart, M . (1998). Citizenship and citizenship education in the U nited States in the 1990s. In O rit I chilov (Ed.), Citizenship and citizenship education in a changing world (pp. 98-129). London: The Woburn Press.

Canfield, J. (1970). W hite teacher, black school. In K. Ryan (Ed.), D on't smile until Christmas: Accounts of the first year of teaching (pp. 25-59). C hicago: University of C hicago Press.

Chant, R. (2002). The impact of personal theorizing on beginning teaching: Experiences of three social studies teachers. Theory and Research in Social Education, 30 (4), 516-540.

Connelly, F. M . and Clandinin, D. J. (1988). Teachers as curriculum planners: N arratives of experience. NYC: Teachers C ollege.

Connelly, F. M ., Clandinin, D. J., and H e, M. F. (1997). Teachers' personal practical knowledge on the professional knowledge landscape. Teaching and Teacher Education, $13(7), 665-674$.

Cornett, J. (1990). Teacher thinking about curriculum and instruction: A case study of a secondary social studies teacher. Theory and Research in Social Education, 18(3), 248-273.

D arder, A. (1999). Afterword, in M. Pruyn, D iscourse warsin G otham-West: A Latino immigrant urban tale of resistance and agency (pp.174-178). Boulder, CO : W estview Press.

D ecker, S. (1969). An empty spoon. N ew York: Scholastic Book Services.

D ewey, J. (1938). Experience and education. N ew York: M acmillan.

Dilworth, M . (1990). Reading between thelines: Teachers and their racial/ethnic cultures. Washington DC: C learinghouse on Teacher Education.

D ucharme, E. and D ucharme, M. (1999). LeslieTurner: A teacher under stress. In R. M cN ergney, E. D ucharme, \& M . D ucharme (Eds.), Educating for democracy: C ase method teaching and learning (pp. 79-94). M ahwah, N J: Lawrence Erlbaum Associates.

Elliot, J. (2000). The challenge of lifel ong learning as a means of extending citizenship for women. Studiesin the Education of Adults, 32 (1), 6-21. 
Feiman-N emser, S. and Buchmann, M . (1989). D escribing teacher education: A framework and illustrative findings from a longitudinal study of six students. Elementary School Journal, 89(3), 365-377.

Fickel, L. (2000). D emocracy is messy: Exploring the beliefs and personal theories of a high school social studies teacher. Theory and Research in Social Education, 28(3), 359-389.

Foley, G. (1999). Learning in social action: A contribution to understanding informal education. Zed Books: London.

Forester, J. (1980) Listening: T he social policy of everyday life (critical theory and hermeneutics in practice). Social Praxis, 7(3/4), 219-232.

Freire, P. (1970). Pedagogy of the oppressed. N ew York: Seabury Press.

Gollnick, D . (1991). M ulticultural education: Policies and practices in teacher education. In C. Grant (Ed.), Research and multicultural education: From the margins to themainstream (pp. 218-239). London: Falmer Press.

Gorard, S., Fevre, R. and Rees, G. (1999). The apparent decline of informal learning. O xford Review of Education, 25(4), 437-454.

Grant, C. (1994). Best practices in teacher preparation for urban schools: Lessons from the multicultural teacher education literature. Action in Teacher Education, 16(3), 1-18.

G rant, C. (1999). Full democracy by students of color: A case from two urban classrooms. In R. M c.N ergney, E. D ucharme \& M . D ucharme (Eds.), Educating for democracy: C asemethod teaching and learning (pp. 175-194). M ahwah, N J: Lawrence Erlbaum Associates.

Grant, C. \& Secada, W. (1990). Preparing teachers for diversity. In W.R. H ouston (Ed.), $\mathrm{H}$ andbook of research and teacher education (pp.403-22). N ew York: M acmillan.

Guttman, A. and Thompson, D . (2000). W hy deliberative democracy is different. Social Philosophy and Policy, 17(1), 161-180.

H all, B. (1999). Social movement learning: Interim report on an international comparative study. Presented at the 1999 World C ouncil of C omparative education, H ong Kong.

H ébert, Y. and W ilkinson, L. (2002). The citizenship debates: C onceptual, policy, experiential and educational issues. In Y. H ebert (Ed.), Citizenship in tranformation in Canada (pp. 3-36). Toronto: University of Toronto Press.

H oward, G . (1999). We can't teach what we don't know: Whiteteachers, multiracial schools. N ew York: Teachers College Press.

H utchinson, A. C. (1989). Waiting for coraf: A critique of law and rights. Toronto: University of Toronto Press.

Ichilov, O . (Ed.). (1998). Citizenship and citizenship education in a changing world. London: The Woburn Press.

Johnston, R. (1999). Adult learning for citizenship: Towards a reconstruction of the social purpose tradition. International Journal of Lifelong Education, 18(3), 175-190.

Jones, E. (Ed.) (1993). Growing teachers: Partnershipsin staff development. Washington D C: N ational Association for the Education of Young Children.

Kahne, J. and Westheimer, J. (2003). Teaching democracy: W hat schools need to do. Phi Delta Kappan, 85(1), 34-36.

Kennedy, K. (1998). Preparing teachers for the new civics education. Asia-Pacific Journal of Teacher Education and Development, 1(2), 33-40.

Knowles, J. G. and H olt-Reynolds, D. (1991). Shaping pedagogies against personal histories in preservice teacher education. Teachers College Record, 93(1), 87-113.

Liston, D . and Zeichner, K. M . (1993). Teacher education and the social conditions of schooling. New York: Routledge

Lowery, L. (1997). T he nature of learning. FO SS N ewsletter \#10, Fall, 11-12.

M agsino, R. (2002). From eclectic theory to coherence: Citizenship virtues for our time. In Y. H ebert (Ed.), Citizenship in transformation in Canada (pp. 57-80). Toronto: UT Press.

$M$ athison, S. and Freeman, M . (2003). Constraining elementary teachers' work: Dilemmas and paradoxes created by state mandated testing. Education Policy Analysis Archives, 11(34). 
Retrieved September 24, 2003, from http://epaa.asu.edu/epaa/v11n34/.

M artin, I. (1999). Adult education, lifel ong learning and active citizenship. Adults Learning, 11(2), 16-18.

M cD onald, J. (1992). Teaching: M aking sense of an uncertain craft. N ew York: Teachers College Press.

M cEwan, B. (1994). D eliberately developing democratic teachers in a year. In J. N ovack (Ed.), D emocratic teacher education: Programs, processes, problems and prospects (pp. 103-124). N ew York: SU NY Series on D emocracy and Education.

M cN ergney, R., D ucharme, E. and D ucharme, M . (Eds.) (1999). Educating for democracy: Case method teaching and learning. N J: Lawrence Erlbaum Associates.

M ishler, W. and Clarke, H. (1995). Political participation in Canada. In M. Whittington \& G. W illiams (Eds.), Canadian politicsin the 1990s (pp.129-151). Toronto: N elson C anada.

Nie, N ., Junn, J. and Stehlik-Barry, K. (1996). Education and democratic citizenship in America. C hicago: University of Chicago Press.

O ntario M inistry of Education and Training (1999). Canadian and world studies.

The 0 ntario Curriculum, G rades 9 and 10. www.edu.gov.on.ca/eng/document/curricul/seccurric.html

O sborne, K. (1991). Teaching for democratic citizenship. M ontreal: O ur Schools/O ur Selves.

Parkay, F. (1983). White teacher, black school: T he professi onal growth of a ghetto teacher. N ew York: Praeger.

Piaget, J. (1952). T he origins of intelligencein children. N ew York: International U niversity Press.

Polanyi, M . (1966). The tacit dimension. N ew York: D oubleday.

Powell, R. (1992). The influence of prior experiences on pedagogical constructs of traditional and nontraditional preservice teachers. Teaching \& Teacher Education, 8(3), 225-238.

Powell, R. (1996). Epistemological antecedents to culturally relevant and constructivist classroom curricula: A longitudinal study of teachers' contrasting worldviews. Teaching \& Teacher Education, 12(4), 365-384.

Proefriedt, W. (1994). H ow teachers learn: Towards a moreliberal teacher education. N ew York: Teachers College Press.

Pruyn, M . (1999). D icourse wars in Gotham-West: A Latino immigrant urban tale of resistance and agency. Boulder, $\mathrm{CO}$ : Westview Press.

Sarason, S.B. (1972). The creati on of settings and the future societies. San Francisco: Jossey Bass.

Schugurensky, D . (2002). Transformative learning and transformative politics: T he pedagogical dimension of participatory democracy and social action: Essays on theory and praxis. In E. O 'Sullivan, A. M orrell \& M .A. O 'C onnor (eds.), Expanding the boundaries of transformative learning (pp. 59-76). N ew York: Pal grave.

Schugurensky, D . and M yers, J. (2003). A framework to explore lifel ong learning: The case of the civic education of civics teachers. International J ournal of Lifel ong Education, 22 (4), 352-379.

Sears, A. (1994). Social studies as citizenship education in English Canada: a review of research. Theory and Research in Social Education, 22(1), 6-43.

Sears, A. (1997). Social studies in Canada. In I. Wright \& A. Sears (Eds.), Trends and issuesin Canadian social studies (pp. 18-38). Vancouver: Pacific Educational Press.

Sears, A., Clarke, G . and H ughes, A. (1999). C anadian citizenship education: The pluralist ideal and citizenship education for a post-modern state. In J. Torney-Purta, J. Schwille $\&$ J. A madeo (Eds.) Civic education across countries: Twenty four national case studies from the IEA civic education project. Amsterdam, the N etherlands: International Association for the Evaluation of Educational Achievement.

Sears, A. and Perry (2000). Beyond civics: paying attention to the contexts of citizenship education. Education Canada, 40(3), 28-31.

Taylor, E. (2003). The relationship between the prior school lives of adult educators and their beliefs about teaching adults. Internati onal Journal of Lifel ong E ducation, 22(1), 59-77. 
Torney Purta, J., et al. (1975). Civic education in ten countries N ew York: Wiley.

Torney-Purta, J., Schwille, J. and Amadeo, J. (1999). Civic education across countries: Twenty-four national case studies from the IEA civic education project. Amsterdam: International Association for the Evaluation of Educational Achievement.

Vella, J. (1994). Learning to listen, learning to teach. San Francisco: Jossey-Bass. Vygotsky, L.S. (1978). M ind in society. C ambridge, M A: H arvard University Press.

Welton, M . (2002). Listening, conflict and citizenship: Towards a pedagogy of civil society. International Journal of Lifelong Education, 21(3), 197-208.

Zeichner, K. and G ore, J. (1990). Teacher socialization. In W.R. H ouston (Ed.), H andbook of research and teacher education (pp.403-22). N ew York: M acmillan.

Zimpher, N . and A shburn, E. (1992). Countering parochialism in teacher candidates. In M. D ilworth (Ed.), D iversity in teacher education (pp.40-62). San Francisco: Jossey-Bass. 